\title{
The Armenian Genocide in the Kurdish Novel: Restructuring Identity through Collective Memory
}

Adnan Çelik and Ergin Öpengin

\section{(2) OpenEdition}

\section{Journals}

Electronic version

URL: http://journals.openedition.org/ejts/5291

DOI: 10.4000/ejts.5291

ISSN: $1773-0546$

Publisher

EJTS

Electronic reference

Adnan Çelik and Ergin Öpengin, « The Armenian Genocide in the Kurdish Novel: Restructuring Identity through Collective Memory », European Journal of Turkish Studies [Online], Complete List, Online since 08 July 2016, connection on 19 February 2020. URL : http://journals.openedition.org/ejts/5291; DOI : 10.4000/ejts.5291

This text was automatically generated on 19 February 2020.

(c) Some rights reserved / Creative Commons license 


\title{
The Armenian Genocide in the Kurdish Novel: Restructuring Identity through Collective Memory
}

\author{
Adnan Çelik and Ergin Öpengin
}

1 The Armenian genocide in 1915, part of the Turkish nation-building project, also marked the beginning of a process which would in subsequent decades culminate in the total disappearance of a millenia-long cohabitation of the Armenian and Kurdish populations in the predominantly Kurdish-inhabited present-day eastern Anatolia. ${ }^{1}$ Until recently, the legacy of the genocide, and the radical changes that it brought to the cultural and material life in the region, were only marginally addressed, given that the dominant public discourses in Turkey have been shaped largely by the genocidenegationist state thesis (cf. Biner 2010: 69, 89). Although limited in number, there have however been efforts among scholars towards investigating Kurdish-Armenian relations and the role of the Kurds in the genocide (cf. Sasuni 1992; Bozarslan 1995; Kieser 2005; Ternon 2007). Some recent research into the oral history of the genocide, on the other hand, has revealed the presence of a robust collective memory among many contemporary Kurdish citizens in Turkey with regard to the Kurdish-Armenian past and the process through which the Armenians were purged from the region (Biner 2010; Üngör 2014; Ege 2011; Çelik, Dinç 2015).

2 An examination of how the Armenian genocide - and Armenians in general - have been represented in modern Kurdish literature seems a useful point of investigation. Modern Kurdish literature, produced by Kurds from Turkey, has become relatively visible only since the 1980s due to oppression and rupture (cf. Zeydanlığlu 2012), and is best understood as still very much an emergent literature. Scalbert-Yücel (2013: 264-268) argues that the primary function of modern Kurdish literature, especially during the 1980s and 1990s when the oppression against the Kurds in Turkey was at its peak, has been one of "bearing witness" by "creating documents" with regard to the state's oppression and persecution of the Kurds. Examining how Kurdish literature has looked at - or ignored - the Armenian genocide thus offers a critical vantage point for 
examining the Kurdish-Armenian past and present. Given that literature is a major component of cultural meaning-making (Neumann 2008: 335), it can provide significant insights into the dominant concepts of the memory existing in the society by revealing the ways in which the memory is treated in literary forms. In fact, following a brief relative silence on the Kurdish-Armenian relations and the memory of the genocide in the literature produced by the first generation of Kurdish writers writing in the European diaspora in the 1980s and 1990s, there has recently been a significant increase in Kurdish novels and short stories addressing the memory of 1915, especially in the works of a younger generation of Kurdish writers producing poetry, short stories and subsequently also novels since late 1990s.

3 This article investigates how a new generation of Kurdish writers in Turkey treats the genocide and the memory of the Kurdish-Armenian past. We start with a literature review showing that in its relationship to the present, collective memory has a constitutive and transformative role in identity. We then describe the silencing effect of official Turkish historiography on Turkish literature with regard to the genocide, and discuss the dynamics that have led Kurdish literature to emerge as a field of counter-memory/discourse on the genocide, one that encourages literary works addressing the memory of the genocide - all the while creating new (Kurdish) discourses within emerging power relations. In our investigation into Kurdish literary works, we evaluate a number of recurring shared themes by focusing on three novels, and we provide a more comprehensive overview of the manner in which 1915 and the Armenians are represented in Kurdish literature. The article ends with a critical discussion on the possibilities and the limits of the increasing presence of genocide memory in Kurdish literature with regard to confrontation with the past.

\section{Literature and past: the dynamics of memory discourses in Turkey}

4 The relation of literature to the past, particularly following the appearance of autobiographical witnessing accounts of Jewish genocide survivors, is widely understood as an important dynamic in confronting the past; this "witnessing literature" has also played a significant role in revealing crimes against humanity and in bringing up the genocide, mass murders, discriminations and exclusions to which the silenced groups are exposed (cf. Wieviorka 2013). More recently, this field has extended to include the witnessing literature that appeared during the processes of confronting the past after the Spanish civil war and following the military dictatorships in Latin America (Sarpkaya 2014). In all three contexts, literary productions often preceded other disciplinary approaches in confronting the dark episodes of the past. Producers of literature often turn out to be more agile than historians and academics in dealing with negated and silenced historical truths. Within literary genres, this is particularly true for novels, which, with their conventionalized plot-lines and highly suggestive myths (Neumann 2008: 341), provide powerful, often normative models for our own self-narration and interpretation of the past, and help unveil the historical facts hidden in the interest of the authorities. In the same vein, Nichanian (2011) argues that literature is the only field that can adequately relate the Catastrophe (Felaket) that the Armenian people went through - even as literature itself can only truly convey the ultimate unrelateablity of that Catastrophe. 
5 In addition to literature's role with regard to bearing witness and confronting the past, many studies have confirmed the important role of literature in representing and constructing the relationship between memory and identity (Erll et al. 2003, cited in Borst 2009). One conceptualization of that relationship is proposed in terms of the "mimesis of memory," which refers to the narrative and aesthetic techniques that literary texts employ in order to represent and reflect the operation of memory (Neumann 2008: 334). According to this three-dimensional model, formulated in Neumann (2005) around Paul Ricouer's concept of mimesis, literary works are already prefigured by their cultural context, contexts that themselves possess certain interpretations of memory and identity. However, literary works select and modify the components of existing cultural and discursive systems, thus configuring representations of memory, offering new possibilities of understanding and seeing the past. This transposition and exploration, can in turn refigure prevailing versions of collective memory in the community by influencing the readers' own understanding and images of the past. In this sense, literary works can be understood to produce, through discourse, the very past they claim to describe, rather than imitating preexisting versions of memory; literary works thus contribute actively to the stabilisation or transformation of regimes or cultures of memory.

6 Taking up this model developed within the frame of memory, identity and literature, it could be hypothesized that those novels from within the marginalized Kurdish literary field that deal with the genocide might reveal suppressed and marginalized versions of memory - albeit probably mostly the memory of the "Kurds" - and thus contribute to the construction of a counter-memory against the hegemonic memory culture, and, in this way, might help empower those individuals and groups who are marginalized and/ or ignored in a symbolic sphere (cf. Neumann 2008: 338, 341). However, this transformative capacity (refiguration) of literature to influence the memory culture and identity perceptions is at most of limited relevance in the context of Kurdish literature in Turkey, since, due to very low literacy rates in Kurdish, Kurdish literature possesses a proportionally very small readership (cf. Öpengin 2012; Jamison 2016). Still, by analysing such literary works, we can observe which versions of the past are foregrounded and which are neglected or occulted in Kurdish literature and through the means of this literature.

7 Some scholars have proposed a division between two types of collective memory, as "official memory" and "living memory" (Bilgin 2013: 15). Official memory is produced by the dominant groups of the society through official historiography. It serves the construction of the collective identity of the group and abides by the requirements of this construction. Living memory, on the other side, is composed by those who have experienced the events, and, as such, is a memory to which its holders are subjected. It is a memory that is constructed by the people who have experienced the pain and torture and felt the threat and fear of the events, and who, as either victims or perpetrators, bear the burden and share either the honour or the shame of the events. It is a living memory due to its constant evolution over time, going through changes and transformations. Of these two types of collective memory, "selecting" the past is at stake in the first one, while in the second the situation is one of being "subjected" to it (Ypersele et al. 2006, cited in Bilgin 2013: 15).

8 Discussing Turkish novels in relation to the memory of the Armenian genocide, Türkeş (2015: 121) exposes the numerical scarcity of any such Turkish novels - out of tens of 
thousands of novels that appeared under the modern Turkish republic - that deal with the deportation of the Armenians (tehcir), and argues that the neglect, absence and non-mention of the Armenian issue in Turkish literature has to do with the construction of Turkish national identity. In those rare novels that do bring up the issue, the crimes of the two sides (Armenians and Turks) are often commensurated and/or placed alongside additional efforts to minimize the crime and responsibility share of the Turkish side (Türkeş 2015: 124). A recurrent pattern of accusing the Armenians is evident through their depiction as forming alliances with the Russians, the English and the French, and by the same token committing massacres against the Turks. To the Turkish authors, just as it was with the Greeks, the fight waged against the Armenians too was a "death-or-perish" struggle, one of "either-them-or-us." The Turks are depicted as an oppressed, good, moral people who are full of love towards the Armenians, and who, despite the prevailing fear, avoid engaging in violence, while the Armenians are represented as disloyal traitors who are driven by hatred and bloodthirst (Türkeş 2015: 123-124). Fortunately, however, there has recently been a growing literary output in Turkish literature that adopts different approaches to the genocide, contributing to the perspective of a true confrontation with the past (further discussion on this point below). Still, the dominant approach in Turkish literature remains the literary replication and reproduction of official Turkish historiography. As will be shown in subsequent sections, Kurdish authors' novels treating 1915, on the other hand, clearly fall outside the official history and sanctioned memory of the Turkish nation-state; as such, many of these novels emerge as a counter-memory that relies on living memory. In the context of the occultation of the memory of the Armenian genocide by the official Turkish historiography and its parallel cultural discourses, the insistent treatment and representation of the memory of genocide in the emerging field of Kurdish literature fulfils a significant function in the building of a counter-memory.

But how, then, should we make sense of this relatively recent emergence of a yearning to relate and represent the Armenian genocide in Kurdish literature, especially considering the prevailing political and cultural discourses in Turkey that are grounded on the very negation of the genocide? First, we should look at the general context of Turkey, where, over the past two decades, there have been important developments regarding confrontation with the past, particularly in the cultural field. The current that kicked off with the witnessing literature focusing on the consequences of the dreadful social trauma created by the September 12, 1980 military coup was continued with the literary output that dealt with the state violence exercised in Kurdish region during the 1990s. Subsequently, the works of Migirdiç Margosyan (e.g. Gavur Mahallesi [Quarter of non-Muslims] in 2000) but especially Fethiye Çetin's Anneannem [My Grandmother] in 2004, the murder of Hrant Dink in 2007, and the increasing discussions about 1915 due to the approach of the centennial anniversary of the genocide, all contributed to the increase in literary works dealing with the Armenian genocide. Thus, the literature hovering around the September 12 military coup, the 1937-38 Dersim massacre, the war in the Kurdish region through the 1990s, and the 1915 Armenian genocide, coupled with the increase in memory-based oral history studies (e.g. Neyzi 2003; cf. Özyürek 2006), points to the construction of a new culture of memory in Turkey based on the perspective of a more genuine confrontation with 
the past, which constitutes the wider context of the relative sensitivity of many Kurdish authors toward the Armenian genocide.

11 In addition to this general background in the wider national context, equally important are the internal dynamics of the Kurdish area in particular, which seem to have led to an increased interest in genocide memory in Kurdish literature. The Kurdish authors who were exiled to Europe in the 1980s kept largely silent on the subject of Armenians and the events of 1915, focusing their efforts on an endeavour to build a national [Kurdish] literature. Leaving aside Mehmed Uzun's late novels Hawara Dîcleyê I-II [The Cry of Tigris], published in 2001 and 2003, which foreground the milennia-long multicultural cohabitation experiences in Mesopotamia, no literary work focuses specifically on the Armenians and the genocide, and very few mention Armenians or the genocide in any direct fashion. This is likely due to the fact that the major motive in the literary activity of the diaspora Kurdish authors was an imagined Kurdistan, and as such, related to the search for a nation-state (cf. Scalbert-Yücel 2013; Galip 2015); while another pertinent factor might be that these authors were writing before the "memory wave" in Turkey.

However, the newer generation of Kurdish authors consists mostly of young men and women who were politicized starting from the beginning of the 1990s within the context of the ongoing war in Turkey and who have gathered together around various magazines, publishing houses and cultural centers, mainly in Istanbul and Diyarbakir. This generation has tackled not only the state violence exercised toward the Kurds but also other historical injustices, in particular the Armenian genocide. This thematic expansion in cultural production strikingly parallels the developments on political grounds within the Kurdish area. The local governments (or municipalities) related to pro-Kurdish political movements, whose number and authority at the local level have steadily increased since 1999, have implemented cultural policies that are inclusive of diverse linguistic and religious communities (cf. Ayata 2009; Scalbert-Yücel 2015; Törne 2015: 14). Accordingly, in the cultural activities organized by these local governments, the discourse of multiculturalism and a nostalgia regarding past cohabitation feature prominently. In parallel to these developments, Kurdish political actors have repeatedly addressed 1915 in terms of a genocide against an autochtonous people of the region while at the same time acknowledging the involvement of their own ancestors in these events (Biner 2010: 78; Törne 2015: 14; Scalbert-Yücel 2015; Khatchadourian 2015). It can thus be argued that the approach of the dominant Kurdish political movement, which - unlike Kemalist ideologies of a monolithic nation and culture fosters the ideal of a multicultural and multi-component society, may well have provided the political-ideological frame for Kurdish authors to rethink the past and reproduce in literary form the historical truths veiled by official history, relying also on the living memory in the society.

\section{The memory of the genocide in Kurdish novels}

13 As mentioned in the introduction, since the beginning of the 2000s but especially in the second half of the 2000s, when literary production moved from the diaspora to major cities within Turkey and Kurdistan, and with the "memory wave" in Turkey, the number of literary works touching on the Armenian genocide has increased dramatically. Among the first of these was Kilama Pepûgî (2000) by Deniz Gündüz, which 
was also the first novel written in Zazaki. ${ }^{2}$ It was followed by such novels as Mehdî Zana's Ay Dayê [O Mom!] (2005), Sabri Akbel's Evîna Pinhan [Hidden Love] (2006), Hesenê Metê's Gotinên Gunehkar [Sinful Words] (2007), Yaqob Tilermenî's Bavfileh [Proselyte] (2009), Îrfan Amîda's Pêșengeha Sûretan [Exhibition of Faces] (2011), Eyub Guven's Guhar [Earring] (2011), Mehmet Devîren's Kortika Filehan [The Well of Christians] (2013), and such short story collections as Felat Dilgeş's Dilşa $a^{3}$ (2003), Amed Çeko Jiyan's Varjabed (2010), M. Elî Kut's Mehkûm [Convict] (2002), Umer Farûq Ersoz's Berenge (2013) and Mehmet Dicle's $T a$ [Thread] (2013). Additionally, a number of short stories dealing with 1915 and the Armenians were published in various magazines. A quite similar development has also taken place in the literature produced in Turkish by Kurdish authors, who deal with 1915 in relation to Kurdish society. Among these are Serdar Can's Nenemin Masalları [The Tales of My Grandmother] (1993), Zülküf Kışanak's Ahparik Sarkis (2011), Metin Aktaş's Harput'taki Hayalet [The Ghost in Harput] (2012), Yusuf Baği’s Ermeni Kızı Ağçik [Armenian Girl Ağçik] (2007), and Yavuz Ekinci's Cennetin Kayıp Toprakları [The Lost Territory of Paradise] (2012). This relative burgeoning of interest in genocide memory in Kurdish literature has recently also been subject to some scholarly evaluations (Yeşilmen 2014; Galip 2013; Çelik 2015).

Although some of these literary works are framed within time periods before or after 1915 and happen to be narratives in which one or a few of the protagonists are Armenian, the central theme distilled or semanticized into the narratives is 1915 and its aftermath. The specific ways in which the memory of 1915 and its aftermath is conveyed and constructed in Kurdish literature will be investigated in two steps. We will first examine more closely the recurrent themes relating to 1915 and the KurdishArmenian past in modern Kurdish literature based on the analysis of three novels. We will then summarize and discuss the more general approaches to 1915 and the recent Armenian-Kurdish history in modern Kurdish literature.

The three novels selected for close thematic analysis are Deniz Gûndûz's Kilama Pepûgî [The Lament of the Cuckoo Bird], Yaqob Tilermenî's Bavfileh [Proselyte], and Îrfan Amîda's Pêşengeha Sûretan [The Exhibition of Faces]. We selected these novels because their storylines are specifically based on the genocide and/or Kurdish-Armenian past, making them "fictions of memory." Furthermore they represent different settings and character types (Alevi-Sunni Kurdish tribes vs. Armenians; politicized and educated youth vs. elder characters in the village context). Finally, the authors of these novels share the similar background of politicization in Kurdish movement in 1990s and can be considered representative of the "young generation" of Kurdish writers described above. The content and structure of these novels are important in making sense of the emerging themes and for contextualizing the ways in which this memory is dealt with in the novels, thus brief synopses of the three novels are in order.

Published in 2000, Deniz Gûndûz's novel Kilama Pepûgî [The Lament of the Cuckoo Bird] is built around the relations among the Sunni Kurdish tribe of the Cibrans, the Alevi Xormek tribe and the Armenians living in the Varto region (of the present-day Mus province). The story is based on the narratives of Ap Gelo, a senior Alevi from the region, reformulated in the novel from the standpoint of a third person narrator. After participating in the Hamidiye troops in 1890s, the Cibran tribesmen intensify pressure on the Alevis and the Armenians, which leads to a gradual deterioration of Alevi-Sunni and Kurdish-Armenian relations. The Alevis and the Armenians in cooperation resist the oppression of the Hamidiye troops. But good relations between the Alevis and the 
Armenians, consolidated by the centuries-long kirve institution, ${ }^{4}$ are disrupted when the chief of the Armenian Committee, Levon, kills 21 Alevi tribesmen. After the decision to deport the Armenians is issued, the Armenian leader Aşot asks for help from the Alevi leader Welî agha, but the latter avenges his tribe by killing Aşot and his family in a plot. When the oppression on the Armenians evolves into the massacres, the Alevis abstain from protecting their Armenian kirves, due to the recently emerged enmity among them, and thus the Armenians are deported and killed in droves while their belongings are usurped. In subsequent years, when the Russian army invades the region, the Armenians seek to revenge themselves and, without discriminating between Sunni and Alevi Kurds, attack villages and massacre the people. Most of the Alevi Kurds escape to Dersim. The narrative thus depicts the social and historical changes in the region from 1890 till 1916, describes the intensification of the ethnic and culturally based divergences, and reveals the unprecedented damage done to the demographic and cultural fabric of the region.

17 Yaqob Tilermenî's Bavfileh (2009) - the very title of which refers to children who are of Armenian origin but have (or rather were made to) become Muslims among the Kurds looks at the experiences of four Kurdish university students in Istanbul, who search for and find a manuscript that tells the story of an Islamicized Armenian called Hedla or Prapoyan, her Armenian name. During the genocide, while Hedla's caravan is on its way from Sakarya to Dayr al-Zor, she is abducted in Mardin by a Kurd. Hedla leads a life full of discrimination and injustices in this village. A Turkish teacher who is exiled to the village writes down Hedla's story to make a novel out of it. Upon taking hold of this manuscript novel, the Kurdish youth Taybet and her three friends become familiarized with the painful experiences that the Armenians have been through on their own land, which helps them establish a relationship of continuity and association with the state violence against the Kurds during the 1990s that they themselves have experienced.

Finally, Îrfan Amîda's Pêş̧engeha Sûretan [The Exhibition of Faces], published in 2011, tells the story of the genocide survivors Aram and Aşxan, brother and sister, running through three generations from Mardin to Istanbul. Aram is raised by a medrese (religiously-based traditional school) teacher and comes to be known in the community as Mullah Selim, while Aşxan is raised as Fatma Khanum at the house of a Kurdish local lord called Temur agha. When at some point Aram learns about his background and the story of his family, he is devastated and sets out to find his sister. He arrives as an imam in her village and starts to live there without revealing his identity to her. He becomes active in leftist political circles. During the military coup he is detained and tortured. Finally escaping to Istanbul, he adopts the name Apê Ûsiv in order to hide his identity. In Istanbul, he meets his sister Fatma's grandson Servan and his girlfriend Zelal, both activists in Kurdish political circles, and through his interactions with them he witnesses the plight of the Kurds amidst the war context of the 1990s. These acts of witnessing make Aram perceive a shared fate between his turbulent personal past and the tragedy befalling the Kurds.

19 In these and many other novels that treat the genocide and Armenian-Kurdish relations, certain themes are insistently foregrounded, sometimes also only "semanticized" into the text without being explicitly put into words. The main themes are the effort to establish a continuity between the victimhood of the Armenians and the Kurds that has taken place in different time periods, the fate of the Armenian children who have (were made to) become Muslims among the Kurds, the revealing of 
one's experiences as an Armenian among the Kurds only as one is dying, and finally the emphasis on the kirve institution that symbolizes Kurdish and Armenian shared past experiences. In what follows, we describe the ways in which these themes appear in the novels.

\section{“Em şîv hûn paşî̃": continuity in victimhood} respectively, were subjected. For instance, in Amîda's Pêsengeha Sûretan, following the military coup, Mullah Selim is detained and being tortured in prison. The state officer torturing him yells at him saying, "The revolution and Kurdistan, are they your business, son of a dog!? You said revolution... your revolution took place in 1915, [you] son of an Armenian." In Tilermenîs Bavfileh too, focusing on the 1990s as dark years for the Kurds and telling the story of Hedla starting from 1915 to that day, the author connects these two cases of victimhood. This is further confirmed by the Armenian painter character of the novel, Arman, who, while drinking with Taybet one night, says, "We are breakfast, you are lunch," pointing to the similarity and continuity between the Kurdish experience in the 1990s and what his people experienced in 1915.

The temporal frame fluctuating between 1915 and the 1990s in Amîda and Tilermenî's novels is informed both by the authors' personal experiences of politicisation during 
the 1990s and by the Kurdish political movement's version of the recent history, and, as a framing device, it seeks to expose the shared fate of being victims of state violence. The Kurdish characters of the novels foreground the continuity in the violence exercised on the two peoples, incorporating thus the plight of the Armenians into the repertoire of their own political struggle, while the Armenian characters emphasize the point that the Kurds are paying the price for not considering the warnings and the invocations of the Armenians during 1915.

Interestingly, in Deniz Gûndûz's Kilama Pepûgî, this continuity of victimhood is established within a reverse configuration. While for the Sunni Kurds, who had an advantaged standing within the Ottoman "millet" system, the state violence and discrimation starts with the establishment of the Turkish nation-state, in the case of the Alevi Kurds the history of violence and victimhood dates back to much earlier periods. As such, the author often refers to the collective violence trauma of the Ottoman sultan Yavuz Selim's (r. 1512-20) massacre of tens of thousands of Alevis and thus establishes the association of victimhood between the Alevi Kurds and the Armenians in relation to the violence exercised by a Sunni alliance, including the Sunni Kurds. This representation is particularly significant as it reveals that the memory of the Armenian genocide is perceived and interpreted in different ways among Sunni and Alevi Kurds.

\section{"Bavfileh": the plight of the Islamicized Armenian children}

Historians estimate the children and women abducted from their caravans of deportation in 1915 and forcibly converted to Islam as numbering in the tens of thousands (Ternon 2007; Kévorkian 2006). Similarly, many oral history studies have emphasized the high numbers of such Islamicized Armenians in the region inhabited predominantly by the Kurds (Tekin 2009; Ritter, Sivaslian 2012; Neyzi, KharatyanAraqelyan 2010; Altınay, Çetin 2011; Çelik, Dinç 2015).

Islamicized Armenians come up very frequently as a theme in the Kurdish novels treating the genocide. In Kurdish, the term "bavfileh" is used to refer to those individuals who are either partly or entirely from Armenian descent and who were raised among the Kurds as Muslims. The term stands as the very title of Tilermenî's novel, which might be seen as an effort by the author to foreground the widespread nature of the phenomenon. In Bavfileh, when passing by Mardin in a deportation caravan, the nine-year-old Prapiyon is abducted by a Kurdish man, made to become Muslim under the name Hedla, and married to a poor man in the village. The following excerpt indicates the troubles of being of Armenian descent in her daily life:

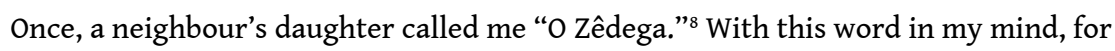
days I pondered on that catastrophe. In spite of them annihilating all my relatives with no compassion whatsoever, I was still seen as an unwanted addition. ${ }^{9}$

From the very first day that she is taken to the village, she gets scolded, looked down upon and demeaned. As in the above quotation, this exclusion wounds her from the inside, and she adds, "Although they call the surviving Armenians 'the remainder of the sword,' the most suitable expression for our situation is 'zêdega." 10 That is, the life of the Armenians who escaped or were saved following 1915 were best described in terms of being misplaced, being "additional" and "left over" where they ended up. Thus, Tilrmenî's Bavfileh provides important insights into the ways in which the surviving 
Armenians were perceived and treated in the Kurdish community, emphasizing the dreadfulness of their experiences and the prevalence of prejudices against them.

Similarly, in Pêşengeha Sûretan, the siblings Aşxan and Aram are handed to the Kurdish Temur agha by their families. Aşxan is renamed as Fatîma and Aram as Selim. Fatîma lives with Temur agha as a "navmalî," that is a person who is part of the household taking care of the house chores, and is forced to marry the son of Temur agha. Her brother Aram is handed to the imam of the village to be raised by him. When the imam moves to another village, Fatîma loses track of Aram and thus loses her last connection with her Armenian past. And until, finally, on her deathbed when she tells her sorrowful tale to the imam of the village, Mullah Selim (unaware that he is in fact her brother), she has lived her life in full silence regarding her past among people towards whom she feels alien.

\section{"Sekerat": telling their truth as they lay dying}

30 Das and Nandy (1985: 187-189) cast doubt on the ability of the language of academic analysis to grasp the extent of the violence against women and the mythical dimensions of their experiences in the case of civil wars, genocide and political partitions. They consider literature more apt for this task, since it is through literary language that the individual-level traumas of men and women, and the experiential level of large-scale social events, can be expressed. Parallel to this argument, in some literary works by Kurdish authors, Islamicized Armenians are allowed to tell their sorrowful personal tales in their full extent only on the deathbed (sekerat).

31 In Pêş̧engeha Sûretan, Aşxan, as she lies dying, yells in the face of the imam all the truths that she had buried in her heart for a whole lifetime. The child Aşxan lost her family, was inserted into a new life context with a changed name and religion, bereft of background and separated from her brother; it is on her deathbed that she suddenly commands the strength to tell her truth and begin recounting the suffering she has experienced since her childhood. The first point she brings up is her religious dilemma that started at the age of nine or ten when she was taken from her family and made to convert to Islam: "One day I am a follower of Muhammed, one day of Jesus, o imam. One day a Muslim, one day a Christian!" ${ }^{11}$ Although totally cut off from her past, she continues to keep her identity a secret, in such a disguised manner as not to leave any room for suspicion on the part of her surroundings. She shows the imam the patterned cross that she has been hiding beneath her pillow for all these years and adds: "I am Armenian, o Master, or, as they say, a 'bavfileh.' I am not only a 'bavfileh,' but a 'fileh. ${ }^{12}$ Remaining from God's day of apocalypse, from the day of annihilation." ${ }^{13}$

It is interesting to note, both in oral history accounts and in literary works, ${ }^{14}$ the frequency of this narrative: in which women like Aşxan, who have paid the price of surviving the genocide in the social violence to which they are subjected all their lives, rise up to break the silence associated with their character in their very last moments before dying. It is a conscious act of proclaiming the truth through breaking a longheld silence, but it also points to the widespread suspicion on the part of the Muslims in the community towards Islamicized Armenians; it is this persistent suspicion about their widely known but unacknowledgeable background that leads the bavfileh to silence their "Armenian side" while living in the wider community. 


\section{"Kirîv": the nostalgia of the lost cohabitation} period, Kieser (2005: 33) convincingly argues that there never was a "millet" system in the eastern provinces functioning in the same way as in the capital, but rather that a certain modus vivendi was attained thanks to observing apparent hierarchical relationships. A form of "tolerable cohabitation" was established between the Kurds and the Armenians. It appears that one institution contributing to the organization of the Kurdish-Armenian cohabitation was the so-called "kirîvatî" (Turkish kirve), which in practice stands for a type of circumcision sponsorship and leads to a particular type of relationship-building between families who might not otherwise be related to each other. This is indeed what the oral history interviews conducted in Diyarbakir (Çelik, Dinç 2015: 53-84) clearly point to, namely that the kirîvatî as a social institution played a crucial role in the organization of the social and political life and the relationships of the Armenians and the Kurds. By on the one hand preventing inter-religious marriages - since people from kirve families cannot marry each other - and by on the other hand establishing a tutelage or protective relation between the Kurds who held a more advantaged position within the millet system and the Armenians who were at the lower levels of the social hierarchy, this institution created social, economic and cultural interactions among the people living in the region.

Not surprisingly, the kirve relationship between the Kurds and Armenians surfaces frequently in Kurdish novels and stories treating the Armenians. In many instances, the Armenian and Kurdish novel characters address each other as "kirîv" (my kirve). The positive aspects of Kurdish-Armenian relations are remembered or recalled through the near-constant emphasis on being kirves. For instance, in the "fiction of memory" novel Kilama Pepûgî, the kirve institution is the very basis of Kurdish-Armenian relations. Thus, the Armenians are constantly benefitting from the protection of their Alevi Kurdish Xormek tribe kirves against the oppression of the Sunni Kurdish Cibran tribe and the Ottoman soldiers. The law of kirve binds the involved parties socially and economically. For instance, in the same novel, the chief of the Xormek tribe is killed by the Cibrans. When the two sons of the chief, Welî and Mem, arrive in Istanbul in order to inform their elder brother Zeynel about the event and take him back home, they are hosted by their Armenian kirve Kebo Efendi. Welî cannot help looking at the young women in his host's house, "forgetting himself and even the fact that they are kirves, since when the two sides are kirves they can never marry each other." ${ }^{15}$ Similarly, the Armenian Serko, in his kirve Zeynel's house, "would fall breathless when he beheld the women. According to the [traditional] law he was supposed to look at his kirves just as he looks at his sisters. Not following this principle would amount to a big sin." 16 Similarly, when Welî agha exacts revenge on the Armenian Levon by killing his kirve Aşot and his family, some of the tribe members cannot accept the situation on the grounds that a kirve is equal to one's brother and thus should not be killed no matter what the reason. This consciousness of guilt stemming from killing the kirve attains a symbolic dimension in the last sentence of the novel. Having migrated to Dersim due to the war, Zeynel and his family settle in a house only to find out that a cuckoo bird has made its nest in one of the walls, crying day and night, and not letting the household sleep. An Alevi elder (pîr) comments on this in the following way:

Son, that cuckoo is Aşot himself. Aşot who is your kirve. He has disguised himself in the form of a cuckoo bird. Every night by crying he calls Welî. He curses him. That 
is why Welî cannot sleep (...). Because Welî agha killed his kirve (...). Welî agha

annihilated Așot and his children at the valley. ${ }^{17}$

Here, the Alevi elder interprets the wailing of the cuckoo in the wall as a constant calamity that befalls Welî agha in return for his killing Aşot and his family at the cost of violating the kirve law. Again, at the beginning of the novel, we find the narrator Uncle Gelo's statement as cited above, "We were kirve, we were brothers (...). The story of the Kurds and the Armenians was the story of the cuckoo bird. They had (...) killed their brothers." This is a symbolic narrative exposing the idea that perpetrators could never finally escape the injustices they committed during the genocide. In that sense, it is parallel to the narratives of what Çelik and Dinç (2015: 174) call "symbolic confrontation," in which people must pay the price of having taken part in the genocide by way of various calamities that befall them later in their lives.

In some other Kurdish novels, on the other hand, the Armenian-Kurdish kirve-based sociality that loses its magic and validity under the genocide conditions in Kilama Pepûgî is invoked through nostalgia of a shared past life and used to idealize the relations between the communities. For instance, in Eyup Guven's Guhar, which focuses on the daily life of the genocide survivors in the Derik town of the 1950s, the author foregrounds extensively the presence of kirve ties between the Kurds and the Armenians when he makes reference to the peaceful cohabitation between the two people. In Bavfileh, on the other hand, the Armenian painter's reaction to the idealization and nostalgic narratives around the kirve-based relations of the two communities is more realistically depicted. As he says, "All of the Kurds say that we and the Armenians are kirves. This is true, but they have also brought blood and death to their kirve relations." 18

\section{Approaches to genocide and history in Kurdish literature}

In addition to these specific recurrent themes, Kurdish literary works share also a lot in their approach to the genocide and history. A feature found across most of the novels is an engagement in a particular type of de-historicization, such that in most of the novels touching upon the role of the Kurds in the 1915 events, the real agent of the acts is the state, that is the Ottoman/Turkish government; in this rendering, particular groups of the Kurds are "deceived" by the state's tricks and become "instruments" in the massacres. In the same vein, many of these authors seem to evaluate, analyse and judge 1915 from the standpoint of the present day. As a result, in many novels there are either very bad or very good Kurdish characters, while the quasi-totality of the Armenians are victims, destitute and very good people.

Another fact, pointed out also by Yeşilmen (2014), is that rather than addressing the reasons and/or the process of 1915, the novels focus on consequences. The most frequently recurring narrative around the consequences is one that establishes a continuity between the catastrophes that the Armenians went through and the devastations that the Kurds would in subsequent years and decades experience, pointing to the common agent behind the plight of the two peoples as the Ottoman Empire and the new Republican regime that succeeded it. This focus sets aside questions of guilt, intention, responsibility (and to whom those must belong) in favor of focusing on agentless victimhood and a redemptive continuity between Armenian 
suffering in the early 20th century and Kurdish suffering in later decades, mobilizing the former for the sake of bolstering the latter.

A commonly shared point in the novels is the centrality of the experiences of the girls and boys who were abducted or saved in 1915 and subsequently Islamicized. Quite a few of the stories are shaped around the witnessing and experiences of the survivors, which creates the impression that the authors develop narratives based on similar stories that they have heard in real life. In fact, recent research in the oral history of the Diyarbakir (Çelik, Dinç 2015), Mardin (Biner 2010) and Van (Ege 2011) regions has revealed that, throughout the past decades, there has been a remarkable transmission of memory through the personal witnessing and experiences of the women and children who survived the genocide and lived among the Kurds, most of the time as Muslims of a specific category termed bavfileh, literally "those from Christian parents." ${ }^{19}$

It thus seems as if the authors reproduce in literary form the witnessing accounts that they have acquired through their subjective experiences and encounters with the collective memory of their social milieus, thanks to the robust memory and narrative circulation regarding the genocide and the Armenians within Kurdish society. The treatment of the Armenian genocide in Kurdish literature, in this sense, can be understood as the witnessing of witnessing, since none of the novelists in fact lived through 1915, but rather set out from the collective memory of the Kurdish society to produce second-hand or indirect witnessing of the events. This circle of factors and motivations together with the resulting literary activity confirms the fact that these works, some of which are indeed "fictions of memory" per se, contribute to the individuals' or the community's own quests of identity by reformulating the witnessings that exist inside the society through the possibilities offered in literature.

The continuity between oral history and modern literary accounts of 1915 and its aftermath in Kurdish literature is rather straightforward. What is more difficult to estimate is the extent to which these literary representations of the genocide and its aftermath compare to the actual history of the genocide, especially with regard to the responsibility of the Kurds in it. The difficulty is mainly because the "actual history" of the role of the Kurds in genocide is far from being clear. Existing studies (e.g. Sasuni 1992; Bozarslan 1995; Kieser 2005; Ternon 2007; Kévorkian 2006) consider the role of the Kurds on different levels (from active participation to the massacres to protections of the victims) and with respect to different actors or interest groups (from tribal leaders and paramilitary groups to ordinary individuals). It is thus not possible to talk of a general category of "Kurds" nor does it make sense to generalise a single approach to the "role of Kurds" in the genocide. Nevertheless, the studies do confirm that some portions of the Kurdish population took part in the genocide. Such active participation of the Kurds in the genocide is rarely depicted in modern Kurdish literature. This is partly a by-product of overemphasis in these literary works on the aftermath of the genocide. Some other references to the direct involvement of the Kurds are hedged either by representing the actors as isolated evil characters ${ }^{20}$ or by lining them up after other groups as Arabs and Circassians. ${ }^{21}$ Still, as in the three novels analysed above, the involvement of the Kurds in the genocide is sometimes voiced in general terms, such as "they had killed their brothers" (Kilama Pepûgî, p. 3) or "they have also brought blood and death into their kirves" (Bavfileh, p. 47). among the Kurds and its representation in literature, it should be noted that there are 
various other accounts of the genocide within Kurdish society and politics. Some accounts are relatively closer to the negationist version of the state, as illustrated in the context of the city of Van by Ege (2011: 60-64). Some Kurdish nationalistic discourses, on the other hand, foreground the idea that the Kurds were instrumentalized and that the Armenians also waged massacres against the Kurds. In such accounts, the Kurds' responsibility in genocide is denied while the plight of the Armenians is implicitly legitimized on the grounds of counter-violence directed to Armenians due to their hostilities and collaboration with external forces. ${ }^{22}$ To the best of our knowledge, such approaches to 1915 have not yet been represented in the modern Kurdish literature, which is why we have not paid heed to them in our discussion.

\section{Potentials and limits of Kurdish literature in confronting the Armenian genocide}

While at the centenary of the Armenian genocide there is a fierce negationist attitude prevailing in the Turkish state and public opinion, in the Kurdish region important initiatives towards confronting the past are being taken by the local governments and political actors. For instance, on the 24th of April 2015 in Diyarbakir, a genocide commemoration was carried out by the Armenian organizations from the diaspora and Turkey along with some local non-governmental organizations. The Kurdish political movement was represented by its highest-ranking members, namely the mayor of Diyarbakir and the co-chair of the major pro-Kurdish political party HDP (ScalbertYücel 2015). In addition, following the success of the Kurdish political movement in winning local elections since the early 2000s, there have been extensive efforts to protect and restore Armenian cultural heritage in the region, especially in Diyarbakir and its surroundings. ${ }^{23} \mathrm{All}$ of these initiatives can also be interpreted as a declaration of intention by the Kurdish political circles to confront the genocidal past (cf. ScalbertYücel 2015; Ayata 2009; Biner 2010). The increasing presence of the memory of 1915 as a new current in Kurdish literature, which this article has described, should be understood as an extension of these efforts to confront the past. Despite its limited readership, this literature, which heavily draws on the oral history narratives of 1915 within Kurdish society, does possess such a potential. All of these literary works assume a clearly critical perspective toward the past and treat the 1915 events as a major massacre against the Armenians, exposing the alienation and discrimination experienced by the survivors, and establishing a continuity between the genocide and the dreadful experiences subsequently experiened by the Kurds. They reject the heritage of state-induced violence exercised against the Armenians in the past. Nevertheless, many of these literary works focus more on the consequences rather than the process of the genocide, and on the life experiences of genocide survivors among the Kurds. In so doing, they adopt a de-historicizing narrative line and style, neglecting or silencing the local-level personal motivations and the dynamics of the societal discordances in Armenian-Kurdish relations with regard to the genocide.

On the other hand, with the insistent treatment of the violence in the region's recent past, foregrounding the memory-history relationship, Kurdish authors have turned the emerging Kurdish literature into a space of memory. This parallels the findings of fieldbased oral history research carried out among the Kurds (Biner 2010; Ege 2011; Tekin 
2013; Çelik, Dinç 2015), which maintains that the Armenian genocide occupies a central place in the collective memory of the Kurds. In this sense, these literary works contribute to the building of a counter-memory based on the living memory of their community, which is also empowered by the political discourse, thus challenging the official version of memory promoted by the negationist state-centric historiography. And as such, the appearance of Armenian and 1915 narratives in Kurdish literature can be seen as an effort to construct collective memory.

If we are to formally express how that memory-building process might be proceeding in the context of Kurdish literature, relying on the concept of the "mimesis of memory," firstly, the Kurdish authors are surrounded by three major different cultural and discursive systems on the genocide: on the one hand, the negationist approach - or "post-genocidal habitus of denial," as conceptualized in Suciyan (2015:21-27) circulated by the state's ideological instruments; on the other hand, their own version of the past that builds upon the oral culture influential in the authors' familial surroundings; and, finally, as individuals taking part in the Kurdish political movement - especially during the politically intense 1990s - their interactions with the Kurdish movement's interpretation of the history and the past, which distinctly opposes the official historiography of the Turkish nation-state. The works of the authors are prefigured within these three discourse frames.

Secondly, by rejecting the negationist approach of the state toward history, inspired by the narratives with which they are connected through their familial background, and positioned within the confines of the pluralist and nationalism-critical discourse of the Kurdish movement, these literary works configure memory representations of KurdishArmenian relations that clearly fall outside the hegemonic negationist version of the past. Nevertheless, even this configuration foregrounds certain interpretations or narratives while occulting or neglecting others. For instance, focusing on the consequences rather than the process of the genocide on the one hand allows for the incorporation of the sorrowful life experiences of the survivors among the Kurds into emerging memory representations, while, on the other hand, this focus on historical consequences over processes leaves the discussion of agencies (especially the role of the Kurds) during the very process of the genocide outside of this memory. The selectivity at this configuration stage confirms the tight relation between memory and identity.

47 Finally, the confrontation and the oppositions between these new memory representations and the prevailing negationist memory culture contribute to the construction and dissemination of different and more critical approaches to the genocide and history; in so doing, these literary works refigure the very collective memory they are born into. The capacity of Kurdish literature to affect or refigure the prevailing collective memory, as apparent from the discussions above, lies in perceiving and representing the state violence against the Armenians and the Kurds as continuous, or at least as located within a continuous tradition. The association of victimhood developed through this very relation of continuity, by making a new generation of Kurds sympathetic towards the sorrows of the Armenian people, enables the re-activation of genocide memory among the Kurds. However, as we have seen, the Kurds' commensurating their own plight with the Armenian genocide bears the risk of instrumentalizing this memory. 


\section{BIBLIOGRAPHY}

Altınay, Ayşe Gül; Çetin, Fethiye (2011). Les Petits-Enfants; Vuraler, Célin (transl.), Arles, Actes Sud. Ayata, Bilgin (April 25, 2009). "Critical Interventions: Kurdish Intellectuals Confronting the Armenian Genocide," Armenian Weekly, pp. 27-29.

Bilgin, Nuri (2013). Tarih ve Kolektif Bellek, Istanbul, Bağlam Yayıncılık.

Biner, Zerrin Özlem (2010). "Acts of Defacement, Memories of Loss: Ghostly Effects of the ‘Armenian Crisis' in Mardin, Southeastern Turkey,” History and Memory 22 (2), pp. 68-94.

Borst, Julia (2009). “Violence et mémoire dans le roman haïtien contemporain," Les Caraibes: convergences et affinités 10. URL: http://publifarum.farum.it/ezine_pdf.php?id=103

Bozarslan, Hamit (1995). "Remarques sur l'histoire des relations kurdo-arméniennes," The Journal of Kurdish Studies 1, pp. 55-76.

Çelik, Adnan (2015). “Hafıza Rejiminde Yeni Bir Alan: 1915, Kürtler ve Edebiyat,” Birikim 132, pp. 27-32.

Çelik, Adnan; Dinç, Namık Kemal (2015). Yüzyıllık Ah! Toplumsal Hafızanın İzinde 1915 Diyarbekir, Istanbul, İsmail Beşikci Vakfı Yayınları. URL: http://www.aciktoplumvakfi.org.tr/pdf/ 100yillikahibv.pdf

Das, Veena; Nandy, Ashis (1985). "Violence, Victimhood, and the Language of Silence," Contributions to Indian Sociology 19, pp. 177-195.

Ege, Gözde Burcu (2011). Remembering Armenians in Van, Turkey. MA Thesis, Sabancı University. Erll, Astrid; Gymnich, Marion; Ansgar, Nünning (eds.) (2003). Literatur-Erinnerung-Identität: Theoriekonzeptionen und Fallstudien, Trier, WVT.

Galip, Özlem (2015). Imagining Kurdistan: Identity, Culture and Society, London-New York, I. B. Tauris.

Galip, Özlem (June 1, 2013). “The Politics of Remembering: Massacres against Non-Muslims in Kurdish Novelistic Discourse," Paper presented at the Hrant Dink Workshop, Istanbul.

Gourlay, William (30 March 2014). "Resurrecting Surp Giragos: Searching for Reconciliation in South-East Turkey”. URL: http://www.stambouline.com/2014/03/resurrecting-surp-giragos.html Haig, Geoffrey; Öpengin, Ergin (2014). “The Kurdish Language: A Critical Research Overview,” Kurdish Studies 2 (2), pp. 99-122.

Jamison, Kelda (2016). "Hefty Dictionaries in Incomprehensible Tongues: Commensurating Code and Language Community in Turkey," Anthropological Quarterly 89 (1), pp. 31-62.

Khatchadourian, Raffi (January 5, 2015). "A Century of Silence: A Family Survives the Armenian Genocide and its Long Aftermath," The New Yorker. URL: http://www.newyorker.com/magazine/ 2015/01/05/century-silence

Kévorkian, Raymond H. (2006). Le Génocide des Arméniens, Paris, Odile Jacob.

Kieser, Hans-Lukas (2005). Iskalanmış Barış: Doğu Vilayetlerinde Misyonerlik, Etnik Kimlik ve Devlet 1839-1938, Istanbul, İletişim. 
Neyzi, Leyla (2003). “Exploring Memory through Oral History in Turkey," in Todorova, Maria (ed.), National Identities and National Memories in the Balkans, London, C. Hurst and Co., pp. 60-76.

Neyzi, Leyla; Kharatyan-Araqelyan, Hranush (2010). Speaking to One Another: Wish They Hadn't Left. Whom to Forgive? What to Forgive?, Bonn, Adult Education and Oral History Contributing to Armenian-Turkish Reconciliation.

Neumann, Birgit (2008). "The Literary Representation of Memory," in Erll, Astrid; Nünning, Ansgar (eds.), Cultural Memory Studies, Berlin, De Gruyter, pp. 333-343.

Neumann, Birgit (2005). Erinnerung-Identität-Narration. Gattungstypologie und Funktionen kanadischer Fictions of Memory, Berlin-New York, De Gruyter.

Nichanian, Marc (2011). Edebiyat ve Felaket; Sönmezay, Ayşegül (transl.), Istanbul, İletişim.

Öpengin, Ergin (2012). "Sociolinguistic Situation of Kurdish in Turkey: Sociopolitical Factors and Language Use Patterns," International Journal of the Sociology of Language 217, pp. 151-180.

Özyürek, Esra (2006). The Politics of Public Memory in Turkey, Syracuse, Syracuse University Press. Ritter, Laurence; Sivaslian, Max (2012). Les Restes de l'épée : les Arméniens cachés et islamisés de Turquie, Paris, Thadée.

Sarpkaya, Doğuş (2014). “Geçmişin Uçucu Imgesinin Peşinde: Felaket, Hesaplaşma ve Edebiyat," Ayrıntı Dergi 2, pp. 135-142.

Sasuni, Garo (1992). Kürt Ulusal Hareketleri ve 15. Yüzyıldan Günümüze Ermeni Kürt Ilişkileri, Istanbul, Med Yayınevi.

Scalbert-Yücel, Clémence (May 11, 2015). “Diyarbakır 'l'Arménienne'. Retour sur la (re)construction d'une ville multiculturelle”. URL: http://ovipot.hypotheses.org/11188

Scalbert-Yücel, Clémence (2013). "La Littérature kurmanci de Turquie comme une littérature de résistance," in Bozarslan, Hamit; Scalbert-Yücel Clémence (eds.), Joyce Blau: l'éternelle chez les Kurdes, Karthala, Paris, pp. 255-271.

Suciyan, Talin (2016). The Armenians in Modern Turkey: Post-Genocide Society, Politics and History, London, I.B. Tauris.

Tekin, Gülçiçek Günel (2013). Beni Yıkamadan Gömün Kürtler Ermeni Soykırımını Anlatıyor, Istanbul, Belge.

Tekin, Gülçiçek Günel (2009). Kara Kefen. Istanbul, Belge.

Ternon, Yves (2007). Mardin 1915 : Anatomie pathologique d'une destruction, Paris, Geuthner.

Törne, Annika (2015). “'On the Grounds Where They Will Walk in a Hundred Years' Time': Struggling with the Heritage of Violent Past in Post-Genocidal Tunceli," European Journal of Turkish Studies 20. URL: http://ejts.revues.org/5099

Türkeş, Ömer (2015). “Tarihi Değil Güncel Bir Felaket,” Ayrıntı Dergi 10 , pp. 120-129.

Üngör, Uğur Ümit (2014). "Lost in Commemoration: the Armenian Genocide in Memory and Identity," Patterns of Prejudice 48 (2), pp. 147-166.

Wieviorka, Annette (2013). L’Ère du témoin, Paris, Fayard/Pluriel.

Yeşilmen, Dawid (2014). "Di Romanên Kurdî de Avakirina Karekterên Ermen û Temsîla Wan," Wêje û Rexne 2, pp. 56-64. 
Ypersele, Laurence Van; Claisse, Stéphanie; Klein, Olivier; Lemoine, Thierry et al. (2006). Questions d'histoire contemporaine : conflits, mémoires et identité, Paris, Presses universitaires de France.

Zeydanlığlu, Welat (2012). “Turkey's Kurdish Language Policy,” International Journal of the Sociology of Language 217, pp. 99-125.

Cited literary works

Akbel, Sabrî (2006). Evîna Pinhan, Diyarbekir, Nûbihar.

Aktaş, Metin (2012). Harput'taki Hayalet, Istanbul, İletişim.

Amîda, Îrfan (2011). Pêşengeha Sûretan, Amed, Lîs.

Baği, Yusuf (2007). Ermeni Kızı Ağçik, Istanbul, Pêrî.

Can, Serdar (1993). Nenemin Masalları, Istanbul, Umut Yayıncılık.

Jiyan, Amed Çeko (2010). Varjabed, Amed, Lîs.

Çetin, Fethiye (2004). Anneannem, Istanbul, Metis.

Devîren, Mehmet (2013). Kortika Filehan, Istanbul, J\&J.

Dicle, Mehmet (2013). Ta, Istanbul, Avesta.

Dilgeş, Felat (2003). Dilşa, Istanbul, Elma.

Ekinci, Yavuz (2012). Cennetin Kayıp Toprakları, Istanbul, Doğan Kitap.

Ersoz, Umer Farûq (2013). Berenge, Diyarbekir, Roşna.

Gûndûz, Deniz (2000). Kilama Pepûgî, Ankara, Vartan.

Guven, Eyub (2011). Guhar, Amed, Ronahî.

Kışanak, Zülküf (2011). Ahparik Sarkis-Așağı Mahalle Yok Artık, Istanbul, Belge.

Kut, M. Elî (2002). Mehkûm, Stockholm, Nefel.

Margosyan, Mıgırdiç (2000). Gavur Mahallesi, Istanbul, Aras.

Metê, Hesenê (2007). Gotinên Gunehkar, Istanbul, Avesta.

Tilermenî, Yaqob (2009). Bavfileh, Istanbul, Do.

Uzun, Mehmed (2001-2003). Hawara Dîcleyê I-II, Istanbul, Avesta.

Zana, Mehdî (2005). Ay Dayê, Istanbul, Tevn.

\section{NOTES}

1. We would like to thank two anonymous reviewers of EJTS and Annika Törner for their initial criticism and comments on this article. We are also grateful to Kelda Jamison for her help with editing the English of the article and many valuable comments. The remaining shortcomings are the sole responsibility of the authors.

2. Rather than standing for a single or unified language, "Kurdish" is an umbrella term encompassing at least five major language varieties spoken by people identifying (mostly) as Kurds. The two major varieties spoken by the Kurds in Turkey are Kurmanji and Zazaki, each with its own written code and with very low mutual intelligibility between the two. From a purely historical linguistic point of view Zazaki and Kurmanji are distinct language varieties. However, this fact does not relate to the identity of the speakers, nor is it the only criterion 
determining the designation of a language variety (cf. Haig, Öpengin 2014). As such, our inclusion of Zazaki under "Kurdish", or its literature under "Kurdish literature," is informed not by the historical linguistic classification of "Kurdish" varieties but by sociolinguistic factors, namely by the identity perceptions and shared cultural history of the peoples speaking the varieties subsumed under the label "Kurdish".

3. Titles for which English translation is not provided are proper names.

4. A particular form of kinship not based on consanguinity, analogical to godparenthood and circumcision sponsorship. It entails a set of mutual obligations and restrictions, often lasting for generations.

5. "Na şanike Ap Geloyî mi rê serê bon de, vayê şanî ver de qesîkerde. A taw ez hena doman bîyo. Hetanî a waxt mi namê Hermenîya bi xirabîye heşnaybu Lê Ap Geloyî vatene; 'Ma kewraybî me, destbiraybî me.' Ê ke qesîkerd gonya mi onciye, bîye zûya. Gorê vatena dê; 'Mesela Kurdan û Hermaniya, mesala pepbûgî bîye.' Îna koranîye ardibî xo ser, birayê xo kişûbî. Mi a taw zana ke pepbûg şanike nîya. Xelkî dejê xo ebe na usilî vato û kerdo şanike." (p. 3)

6. In this tale, which has slightly variant versions, a brother and sister are sent to forest by their ill-intentioned step-mother to collect cardoon plants (also 'thistle,' 'acanthus'). At the end of a whole day of collecting cardoons, the elder sister checks the bag to find out that there are no cardoons in it. Thinking that her brother had secretly eaten them, she splits his stomach with a knife but finds out that there were no cardoons in it and realizes that their step-mother had given them a bag with a hole and that the cardoons had fallen from it. She washes and buries her brother under a tree, on the bank of a stream. Desperately remorseful at her deed, she prays to God to turn her into a cuckoo bird so that she can eternally call her brother in the surrounding mountains. Her wish comes true and since then, every spring when the cardoons grow, the sister in the form of the cuckoo bird cries sorrowfully for her brother, wanders the mountains, and tells of what she did to her brother.

7. "Bi serê we ketiye şoreş û Kurdistan seh kurê sehan. şoreş he... şoreşa we di 1915an de çê bû dola ermeniyan." (p. 136)

8. The word is derived from zêde "extra, surplus" and the nominalization suffix -ga. It is meant to indicate an additional and unwanted person in the household.

9. “Carekê keça cîranê me ji min re gotibû, 'Zêdegayê'. Ez li ser vê peyvê bi rojan li wê bobelatê fikirîbûm. Ligel ku hemû xizmên min bi bêwijdanî tune kiribûn jî, ez jî weke zêdehî dihatim dîtin." (p. 178)

10. "Her çiqasî ji ermeniyên mayî re digotin bermayiyên şûr jî, peyva ku herî bêtir rewşa me dihundirand, peyva zêdega bû." (p. 178)

11. “Ez rojekê Mihemedî rojekê Îsewî me Mele. Rojekê Misilman rojekê Xiristiyan im Mele!” (p. 170)

12. 'Fileh' is the word used in Kurdish to designate the Christians, especially those in the region, regardless of their ethnic identity.

13. "Ez ermenî me seyda. Wekî tê gotin bavfileh. Ne tenê bavfileh, fileh im. A roja qiyameta Xwedê, a roja qirkirinê me." (p. 171)

14. See Çelik and Dinç (2015) for oral history accounts. Novels by Kurdish authors in which similar themes recur are Felat Dilgeş's Dilşa (2003), Îrfan Amida's Pêşengeha Sûretan (2013) and Yavuz Ekinci's Cennetin Kayıp Toprakları (2012).

15. "Çêneke honde ke rindeke bîye Weli şope kewratine, xo vîra kerde. Dolime ke di hetî bî kewra îndi emr û heyat de, hurdmina heta ra kes jûbîn de nizewiĵno. Torê kewratîne nîyanên o." (p. 65)

16. "Çimê Serkoyî ke ginêne cênîyanê çêyî ra bîna xo bîyêne teng. Gore tore gere kewra zê wayanê xo qayte kewrayanê xo kero. Henî mebo a qate heqî de gunawode pîl yasena." (p. 432) 
17. "Lawo o pûy Aşot o. Kewrayê şima Așot o. Kewto dilqê pûy amo zerê dêsî de halen viraşto. 0 ebe şewe waneno, venga Welî dano. Zawlta dano pira. Welî coka nîşkîno rakuyo (...) Bêrê Welî Axay kewrayê xo kîşt!.. Bêrê Welî Axayî Aşot û domanê Aşotî dere de qir kerdî!..” (p. 528)

18. "Tim kurd dibêjin, em û ermenî kirîvê hev in; Ev rastiyek e, lê xwîn jî xistine navbera vê kirîvatiyê û kuştin jî.” (p. 47)

19. The term "fileh" (also as "fele" and "fileh", from Arabic and/or Aramaic falläh "farmer, peasant') is used among Kurds as a generic term referring to all Christians, sometimes pejoratively, regardless of the ethnicity of the given community. The compound term "bavfileh" consists of bav 'father' and fileh 'Christian' and denotes "someone who is from Christian descent but who has been raised among the Kurds as a Muslim," as such, its meaning is more specific than that of "proselyte."

20. This is the case, for instance, in Mehmet Devîren's Kortika Filehan [The Well of Christians], where a local lord, who has actively taken part in the massacres against Armenians, is depicted as an excessively evil person indiscriminately harming the Kurds and Armenians under his dominion.

21. In Yaqob Tilermenî's Bavfileh, the Islamicized Hedla (Prapoyan) relates a scene of massacre as following: "[T]here the soldiers left us. Upon this, the Circassians, the Arabs and the Kurds took the elderly ones away and killed them in a hidden place. They were taking young and beautiful girls for themselves. (...) I was nine years old. A man called Remê Evdo wanted to take me for himself. Then a Circassian, I know he was Circassian from his hat, stood in front of me, he grabbed my ear lobes and pulled my earrings out. Blood came down on my neck." (pp. 125-126)

22. For a principled categorization of the standpoints regarding 1915 among the Kurds, see Çelik and Dinç (2015: 371-397).

23. The reconstruction of Surp Giragos, one of the most important Armenian churches in the Middle East, supported by the Kurdish municipalities of Diyarbakir, and Armenian language courses offered by the Sur Municipality in Diyarbakir illustrate the case in point. Cf. ScalbertYücel (2005), Gourlay (2014).

\section{ABSTRACTS}

This article examines the recently increasing representation of the Armenian genocide and its aftermath in modern Kurdish literature in Turkey. This recent interest is argued to be nested within the "memory wave" in Turkey, but also motivated by both the pluralist ideological underpinnings of the dominant Kurdish movements in Turkey and a robust oral history transmission within Kurdish society. The memory of the genocide is shown to appear in Kurdish novels through a number of recurring themes, such as a nostalgic past cohabitation, Islamicized Armenians, and a redemptive continuity between Armenian and Kurdish suffering in consecutive decades. The article argues that the treatment of the genocide memory in Kurdish literature contributes to a wider-scale effort of establishing a non-negationist counter-memory, but that its potential for a genuine confrontation with the past is weakened by its selective treatment of the memory whereby issues of responsibility and guilt are often avoided. 
INDEX

Keywords: Key words: Armenian genocide, Kurdish literature, collective memory, identity, literary representation, Turkey

\section{AUTHORS}

\section{ADNAN ÇELIK}

Doctoral candidate in Anthropology, EHESS, Paris, France oskizama@gmail.com

\section{ERGIN ÖPENGIN}

Postdoctoral researcher, Department of General Linguistics, University of Bamberg, Germany ergin.opengin@gmail.com 